\title{
HUMAN RESOURCES TRAINING IN BIOTECHNOLOGY: MICROALGAE FOR BIOFUEL AND WASTEWATER TREATMENT.
}

\section{FORMAÇÃO DE RECURSOS HUMANOS EM BIOTECNOLOGIA: MICROALGAS PARA BIOCOMBUSTÍVEL E TRATAMENTO DE EFLUENTES.}

\author{
Iracema de Oliveira Moraes ${ }^{1}$, Regina de Oliveira Moraes Arruda², Rodrigo de Oliveira Moraes ${ }^{3}$, \\ Maria Josiane Conti Moraes ${ }^{4}$
}

\begin{abstract}
.
The most promising and innovative alternative to biodiesel production is presented by the algae (micro and macroalgae), which have been classified by scientists as a source of third generation biofuels. The large-scale production of biodiesel from microalgae and macroalgae bioethanol production will happen much faster than you think. It is believed that its full commercialization is possible within a few years, and with a competitive price compared to diesel produced from petroleum, the same occurring for bioethanol. The use of seaweed as a feedstock for the production of biofuels has been seen as a less environmentally impactful as the biomass produced on the continent and its potential is very high. Several groups in Latin America (Brazil, of course) are studying micro and macroalgae not only for biofuels production (biodiesel, bioethanol, biohydrogen) but also to do wastewater treatment. This paper will discuss the presentations done in four annual courses $(2010,2011$, 2012, 2013) promoted by the Biotechnology Brazilian Argentine Center, BBAC, and offered to fellowships (sixteen per year), from Brazil, Argentina, Colombia, Paraguay and Uruguay. Arthrospira (Spirulina) platensis was chosen as a cyanobacteria model in the courses, due to its feasibility of cultivation, many publications about the subject and the existence of strains isolated in Brazil.
\end{abstract}

KEYWORDS: Biofuel, Arthrospira platensis, Arthrospira maxima, Spirulina, microalgae, macroalgae, BBAC

\section{RESUMO .}

A alternativa mais promissora e inovadora à produção de biodiesel é apresentada pelas algas (micro e macroalgas), que foram classificadas pelos cientistas como fonte de biocombustíveis de terceira geração. A produção em larga escala de biodiesel a partir de bioalgas de microalgas e macroalgas acontecerá muito mais rapidamente do que você pensa. Acredita-se que sua comercialização completa seja possível dentro de alguns anos e com um preço competitivo comparado ao diesel produzido a partir do petróleo, o mesmo ocorrendo para o bioetanol. $O$ uso de algas marinhas como matéria-prima para a produção de biocombustíveis tem sido menos impactante em termos ambientais, pois a biomassa produzida no continente e seu potencial são muito altos. Vários grupos na América Latina (Brasil, é claro) estão estudando micro e macroalgas não apenas para a produção de biocombustíveis (biodiesel, bioetanol, biohidrogênio), mas também para o tratamento de águas residuais. Este artigo discutirá as apresentações realizadas em quatro cursos anuais (2010, 2011, 2012, 2013) promovidos pelo Centro Argentino Brasileiro de Biotecnologia, BBAC, e oferecidos a bolsas de estudo (dezesseis por ano), do Brasil, Argentina, Colômbia, Paraguai e Uruguai. . Arthrospira (Spirulina) platensis foi escolhida como modelo de cianobactéria nos cursos, devido à sua viabilidade de cultivo, muitas publicações sobre o assunto e a existência de cepas isoladas no Brasil.

PALAVRAS-CHAVE: Biocombustível. Microalgas, Macroalgas, BBAC

\footnotetext{
Engenheira de Alimentos, Curadora da Coleção de Culturas Tropicais da FAT, Diretora Presidente da Probiom Tecnologia Engenheira Agrônoma. Coordenadora do Mestrado em Análise Geoambiental.

Engenheiro de Alimentos, Coordenador da Fundação Tropical de Pesquisas e Tecnologia André Tosello, Diretor Técnico da Probiom

Cientista de Alimentos, analista microbiológica da Coleção de Culturas Tropical
} 


\section{INTRODUCTION}

\section{MICROALGAE FOR FOOD}

The importance of microalgae as a source of protein human nutrition has become more significant in the early 1950s. In addition to the food supply in the United States, microalgae were also object of study in environmental technology with a view that there was an improvement in the wastewater quality when cultivating these microorganisms on the body of groundwater. Work on the Arthrospira .

$\mathrm{sp}$ (Spirulina sp) was stimulated in the 1960's precisely because of the discovery of its use as .

food for the population in the vicinity of Lake Chad (Arthrospira platensis) and population Azteca in Mexico (Artrosphira maxima) and the first test on a small scale plant for the production of $A$. platensis was made by scientists of the Institut Français du Pétrole, using a system of open tanks and synthetic cultivation medium. In that region, poor people already consumed the microalgae as a source of food. The $A$. platensis was dry and in the form of biscuit or flakes, called in the local language "dihé", were sold in the local market.

The use of Artrosphira as a food source is quite significant, and the business that motivates its large -scale production. Their high content of considerable biological value protein and essential acids such as gamma-linolenic acid, vitamin B and other justify their use in nutrition to humans and other animals. In addition, the colorants, such as beta-carotene and other carotenoids, which can enhance the pigmentation in meat and eggs of animals dosed with diet Arthrospira, makes it very attractive for the food industry.

The Arthrospira contain various pigments such as phycocyanin, phycoerythrin, chlorophyll and carotenoids. For Arthrospira, beta-carotene is between $67-79 \%$ of total carotenoids which is $53 \%$ more retinol equivalents to that present in the carrots. The carotenoids are isoprenoids family having forty carbon atoms. These are photosynthetic pigment chlorophyll as well as being important as regards the protection of oxidative damage caused by photo incision of light photons. Beta-carotene is a carotenoid that has a characteristic chromophore hydrocarbon group, due to the presence of eleven conjugated double bonds in its structure. It is synthesized in plants, algae and photosynthetic microorganisms few as an important intermediate in the biosynthesis of various carotenoids, such as zeaxanthin. In manufacturing beta-carotene, the conventional method of extraction takes place by using solvents however, due to the low yield and high amount of solvent used there is a tendency of using alternative techniques such as ultrasound, microwave and supercritical fluid extraction. The development of these extraction techniques can facilitate the large-scale application obtaining Arthrospira of beta-carotene, increasing the portfolio of compounds of interest for the maintenance and human and animal health.

Chlorophyll has chelating characteristic that can promote the recovery of cells, thus being able to be incorporated for therapeutic purposes. Chlorophyll increases the amount of hemoglobin in the blood. For the food industry, it is used as a natural pigment in processed food that has high demand by consumer for natural foods. However, there is need to develop processes to justify obtaining chlorophyll via microalgae cultivation. In this regard, special consideration should be given to $A$. platensis to obtain chlorophyll, since it has a high content of pigment, and cultivation facilities allow enable a process on a large scale.

The Arthrospira has a high protein content (60$70 \mathrm{wt} \%$ ), being a rich source of vitamins, especially vitamin B12 and provitamin A (beta-carotene), minerals and essential amino acids, combined with its ease of cultivation in a hostile environment, it is attractive as raw material for feeding livestock .

and poultry as well as in fish farming industry thus making it a cost effective food source.

For the production of microalgae with the purpose to use as animal feed, must be considered also the possibility of the use of industrial or household waste as a source of nutrients. In the case of poultry, the use of microalgae is justified from an economic point of view since their use in countries where this increase in coloration of the animals and eggs, is advantageous.

\section{WHY TO USE MICROALGAE TO GET BIOFUEL - THE CASE OF Spirulina $s p$}

The first-generation biofuels, extracted from vegetables: corn, wheat, sugar beet and sugar cane for bioethanol production; rapeseed, soybean and sunflower for biodiesel - had much prestige but this is no longer perceived, especially the fact that they went into competition with crops for foodstuff, besides being a major cause of deforestation and soil deterioration. On the other hand, the second generation, that add value to almost all waste plants: wood, leaves, straw, agricultural waste, promises to be more advantageous, however, yields that have been obtained so far remain low and their costs re- 
main high, because the enzymatic technologies employed are very complex.

Thus, the most promising and innovative alternative is presented by the algae (microalgae and macroalgae), which have been classified by scientists as a source of third generation biofuels. The large-scale production of biodiesel from microalgae and macroalgae bioethanol production will happen much faster than you think. It is believed that its full commercialization is possible within a few years, and with a competitive price compared to diesel produced from petroleum, the same occurring for bioethanol. Biofuel production using microalgae need to find the best culture conditions aimed primarily at increasing the amount of lipids in the biomass, allowing its use as raw material for biodiesel production. With this special focus on the use of algal biomass as raw material for biodiesel, production can motivate the implementation of efficient processes for producing Arthrospira, as its multiple uses in the market. However, extraction techniques of these lipids on a large scale must be deeply analyzed, particularly obtaining models and data on the kinetics of the extraction - transesterification process. The analysis of the temperature reaction, catalyst concentration, drying time of the biomass of microalgae and the ratio for the reaction with methanol or ethanol, should be well defined in order to facilitate the process.

Komolafe et al. (2014) studied mixed culture of algae growing in wastewater both to obtain wastewater treatment and biodiesel production.

They verified that Oscillatoria and Arthrospira were fast growing. They reported that Arthrospira contains 55 to $77 \%$ in dry weight of protein, and is rich in polyunsaturated fatty acids such as c-linolenic acid, as Garofalo (2009) also reported. Wastewater was effectively utilized for culturing microalgae without addition of nutrients. A high degree of nitrogen removal and high total coliform removal (up to $99.8 \%$ ) were achieved. The native cyanobacteria-dominated mixed cultures yielded more lipids than the pure and Desmodesmus sp. dominated mixed cultures; in addition, the FAME conversion obtained was higher than the other microalgae cultures studied. The FAME produced after ozonation treatment exhibited a greater degree of saturation. Mixed culture of microalgae (cyanobacteria dominated Oscillatoria and Arthrospira) in reactor 1 reduced the total nitrogen by $55.4 \%$ but in a shorter residence time of 11 days. Xu and Mi (2011) studied Spirulina biodiesel production through in situ transesterification. The co-solvent played a crucial role in this novel technical process.
Among the co-solvents selected in this study, the toluene/methanol system performed best in terms of Spirulina biofuel production. .

Nautiyal et al. (2014a) reported that the single stage process of simultaneous extraction and transesterification results in higher biodiesel yield compared to extraction followed by transesterification in two stages. The spectra of NMR and FTIR and gas chromatographic analysis data showed very clearly that algae biodiesel obtained from Spirulina and pond water algae biomass were composed of fatty acid methyl esters. Gas chromatographic analysis data also showed that algae biodiesel derived from Spirulina and pond water algae is mainly composed of palmitic acid methyl ester. Pond water algae biodiesel has more percentage of oleic and palmitoleic acid methyl ester as compared to Spirulina biodiesel. On the other hand, Spirulina biodiesel has more linoleic and linolenic acid methyl ester compared to biodiesel derived from pond water algae. Fuel properties of algae biodiesel show that biodiesel from Spirulina algae and pond water algae were comparable in quality with that of other conventional biodiesel. Based on the fatty acid composition and the fuel properties, it is concluded that biodiesel produced from Spirulina and pond water algae could be a good alternate to conventional diesel. Nautiyal, $P$ et al. (2014b) presented many advantages of Spirulina algae over another biodiesel sources. .

El-Shimi et al. (2013) investigated the effect of the most important reaction variables on the conversion of Spirulina platensis microalgae oil to biodiesel using the acid-catalyzed in situ transesterification process. Results showed that $100 \% \mathrm{H} 2 \mathrm{SO} 4$ concentration (wt/wt oil) at $65^{\circ} \mathrm{C}$ for $8 \mathrm{~h}$ is the optimum investigated conditions using $15 \mathrm{~g}$ of biomass and 80 $\mathrm{ml}$ of the reacting methanol. The average molecular weight of the Spirulina platensis oil was calculated to be $845.19 \mathrm{~g} / \mathrm{mol}$, reduced to be $284 \mathrm{~g} / \mathrm{mol}$ for the produced FAME. The properties of the produced fatty acid methyl esters confirm the EN 14214 standards that make the microalgae biodiesel a substitute fuel for petroleum-diesel.

The use of seaweed as a feedstock for the production of biofuels has been seen as a less environmentally impactful as the biomass produced on the continent and its potential is very high. Research published in the journal Science (2012) shows the technological innovation of a group of scientists from Bio Architecture Lab (BAL), California, who created microorganisms capable of transforming macroalgae biofuels more efficiently extracting the sugars from 
seaweed and converting into ethanol or renewable chemical elements. "Natural seaweed species grow very fast - ten times more than normal plants - and produce many carbs," said Yannick Lerat, scientific director of the Center for the Study and Improvement of Algae in France. .

Also it should be noted the exponential growth of anaerobic wastewater treatment processes, focused on the production of methane, hydrogen and alcohols of commercial interest that enable especially investment in the productive sector, to treat their effluents, culminating with their commercial gain. .

The fatty acid composition of the biodiesel formed from $A$. platensis biomass correspond to methyl esters of palmitic acid (41.21\%), linolenic acid (17.79\%), linoleic acid (12.64\%), oleic acid $(4.11 \%)$, caprylic acid (3.90\%) and palmitoleic acid (3.39\%) This fact allows the production of biodiesel from $\mathrm{Ar}$ throspira as an alternative to conventional biodiesel, since it presents in its composition of fatty acids methyl ester similar to conventional biodiesel according to ASTM D6751 standards.

Technologies that research the use of biomass to generate energy are also feasible using macro and/or microalgae, as in the case of anaerobic digestion to produce mainly biomethane or biohydrogen and bioethanol production due to the polysaccharides in the biomass composition, once hydrolyzed can be converted by fermentation to the desirable bioproduct. In the case of bioethanol, although microalgae have a relatively low amount of carbohydrates obtained by conventional cultivation, it is possible to manipulate the conditions of the growth process in order to increase the amount of carbohydrates whose values are between 40 and $65 \%$ of the biomass composition to become interesting for use as a carbon source for fermentation. The carbohydrates in the biomass composition are in the form of a biopolymer that should be hydrolyzed prior to subsequent use as a carbon source for bioethanol fermentation. Many of the cellulose hydrolysis processes have been developed for the purpose of obtaining fermentable sugar and these processes can be applied to hydrolysis of the polymer produced by microalgae. In this case, there is an advantage with respect to the composition of the polymer structure, which is free of lignin present in the cellulosic materials. Thus, acid hydrolysis can promote good results. The $A$. platensis contains peptidoglycans, carbohydrates that are presented as a structural material of the cell wall and as intracellular storage material, as glycogen.

\section{HUMAN RESOURCES CAPACITATION IN MICRO/ MICROALGAE USE}

This paper presents elements of four annual courses promoted by the Biotechnology Brazilian Argentine Center BBAC and offered to fellowships (sixteen per year), from Brazil, Argentine, Colombia, Paraguay and Uruguay by the Andre Tosello Foundation (www.fat.org.br) and Probiom Technology (www.probiom.com.br). Each country classifies their fellowships, graduate students through their research national councils (CNPq from Brazil, CONICET from Argentine, COLCIENCIAS from Colombia, CONICYT from Uruguay and the Research Council from Paraguay). The courses (2010, 2011, 2012, and 2013 with $84 \mathrm{~h}$ work each year) were offered to fifty eight (58) Brazilians, sixteen (16) Argentines, four (4) Colombians, seven (7) Uruguayans, and one (1) Paraguayan. Figure 1 presents the distribution of the students chosen by each country and Figure 2 and Table 1 shows the distribution origin and the institutions of the Brazilian students by Brazilian regions.

Figure 1. Distribution of $C B A B$ students by South America.

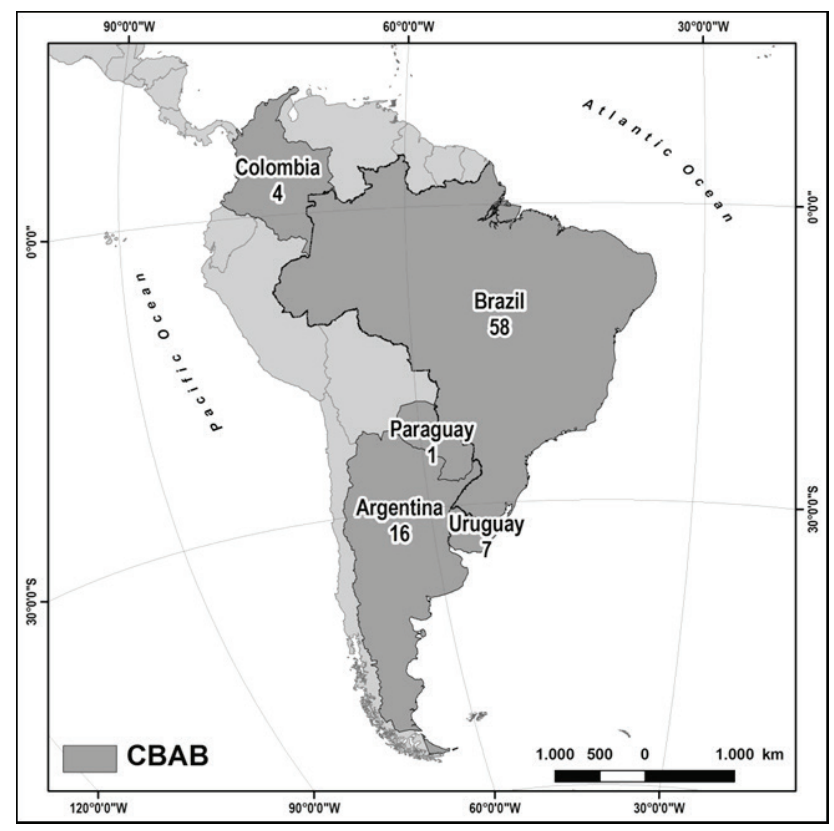

Source: author's own 
Figure 2. Distribution of $C B A B$ students by Brazil.

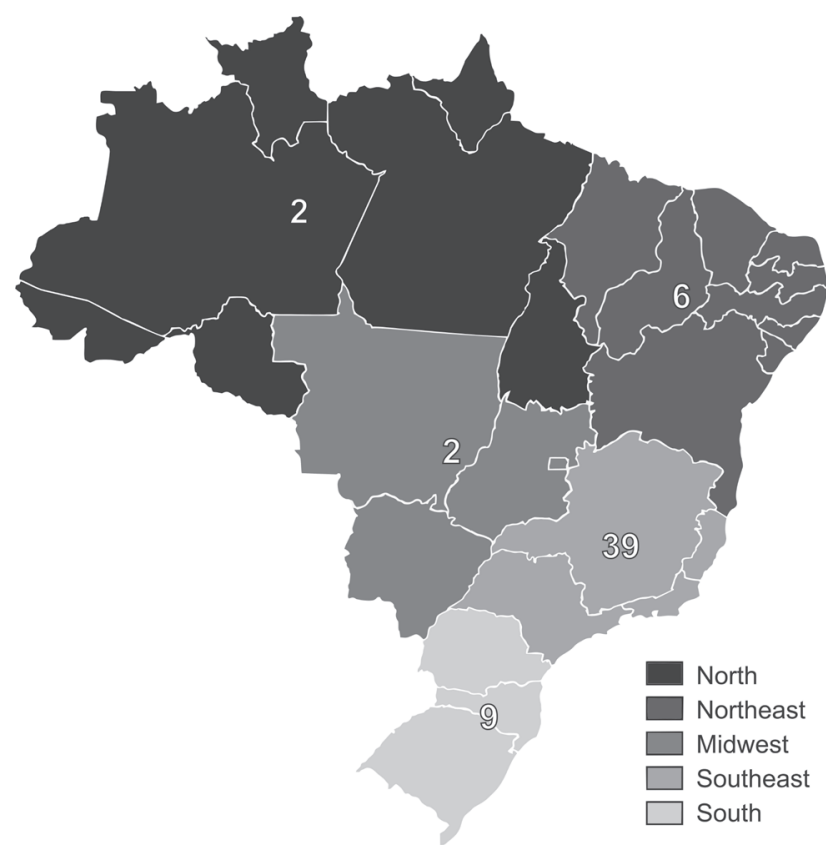

Source: author's own

The BBAC courses, offered $60 \%$ theoretical classes and $40 \%$ experimental, including 24 hours visitations to important centers (four visits of six hours each institution/year) in the subject. Several groups/ institutions in Latin America (Brazil, of course) are studying micro and macroalgae not only for food production, biofuels production (biodiesel, bioethanol, biohydrogen) and also to do wastewater treatment.

Table 1 showed the institutions that originated the fellowships and Table 2 shows the graduate courses of them. Table 3 presents some micro and macroalgae that were treated in the courses, because students were doing master, $\mathrm{PhD}$, or postdoc with this material. The Foundation Andre Tosello (FAT) has an important microorganism's collection of 8000 strains in bacteria, fungi and yeasts, and is beginning an algae collection with the development of lyophilized algae. Most of the Brazilian collections are maintained "in vivo". FAPESP, an important Brazilian foundation, is responsible by the budget get via projects that are in development at FAT. Probiom Technology is responsible by the scale up of the microalgae production processes. Those (FAT and Probiom) were the institutions that organized the courses.
Table 1. Distribution of CBAB students by Brazilian research institution.

\begin{tabular}{|c|l|c|}
\hline Region & Institution & Students \\
\hline \multirow{5}{*}{ Southeast } & UNICAMP & 9 \\
\cline { 2 - 3 } & UNESP & 6 \\
\cline { 2 - 3 } & USP & 6 \\
\cline { 2 - 3 } & UFMG, UFRJ, UFES & 6 \\
\cline { 2 - 3 } & Fiocruz, UMG & 3 \\
\cline { 2 - 3 } & UFSC, UFTPR, ITAL, UFV, Amyris, & 9 \\
\hline \multirow{5}{*}{ South } & Bioetanol, Brasken & 2 \\
\cline { 2 - 3 } & IAPAR & 2 \\
\cline { 2 - 3 } & UFRGS & 3 \\
\cline { 2 - 3 } & FURG, UEL, Embrapa & 2 \\
\hline & CETENE & 2 \\
\cline { 2 - 3 } & UFBA & 2 \\
\cline { 2 - 3 } & UEFS & 2 \\
\hline Midwest & Embrapa & 2 \\
\hline North & Embrapa & 2 \\
\hline
\end{tabular}

Source: author's own

Table 2. Graduated courses that originated the fellowships.

\begin{tabular}{|c|}
\hline Agrarian engineering \\
\hline Applied microbiology \& immunology \\
\hline Biofuel technology \\
\hline Biology \\
\hline Biomedicine \\
\hline Biotechnology \\
\hline Chemical engineering \\
\hline Chemistry \\
\hline Environmental chemistry \\
\hline Environmental engineering \\
\hline Environmental sciences \\
\hline Food engineering \\
\hline Food science \& technology \\
\hline Material engineering \\
\hline Oceanology \\
\hline Pharmaceutical sciences
\end{tabular}

Source: author's own 
Table 3. Micro and macroalgae studied in the institutions involved.

\begin{tabular}{|c|}
\hline Ahnfeltia plicata (Rhodophyta, Ahnfeltiales), \\
\hline Arthrospira (Spirulina) platensis \\
\hline Botryococcus sp \\
\hline Chlorella pyrenoidosa \\
\hline Chlorella sorokiniana \\
\hline Chlorella sp \\
\hline Chlorella vulgaris \\
\hline Chondracanthus chamissoi (Gigartinales, Rhodophyta). \\
\hline Cyanobacterium microcystis \\
\hline Cyanobacterium taxons \\
\hline Cylindrospermopsis raciborskii \\
\hline Gayralia brasiliensis sp. nov. (Ulotrichales, Chlorophyta) \\
\hline Gracilaria domingensis (Gracilariales, Rhodophyta). \\
\hline Hypnea edeniana sp \\
\hline Hypnea species (Gigartinales, Rhodophyta) \\
\hline Kappaphycus alvarezii (Gigartinales, Rhodophyta) \\
\hline Microcystis aeruginosa \\
\hline Neochloris oleoabundan \\
\hline Nostoc sp \\
\hline Ochtodes secundiramea (Rhodophyta) \\
\hline Ulva lactuca (Ulvophyceae, Chlorophyta) \\
\hline
\end{tabular}

Source: author's own

\section{FINAL CONSIDERATIONS}

It is very important micro and macroalgae studies for biofuels or for food additives production. Human resources capacitation in these themes, is an important topic to latinamerican professionals. The country from where the students came are rich in water pounds and have a big diversity of micro and macroalgae, that need to be explored to get them added value.

\section{Acknowledgements.}

FAPESP - São Paulo Research Foundation: processes 2013/24669-7 and 2009/54946-7.

CNPq - National Council of Research and Development: processes 401831/2009-4, 402596/2010-2, 400725/2011-8 and 403014/2012-3. 


\section{REFERENCES}

ARRUDA, Regina de Oliveira Moraes et al. Fermentação de Spirulina platensis sob condições Naturais de Temperatura e Insolação. Revista Saúde-UNGSer, v. 3, n. 3, p. 16-19, 2009.

EL-SHIMI, H. I. et al. Biodiesel production from Spirulina-Platensis microalgae by in-situ transesterification process. Journal of Sustainable Bioenergy Systems, v. 3, n. 3, p. 224, 2013.

GAROFALO, Raffaello et al. Algae and aquatic biomass for a sustainable production of 2 nd generation biofuels. AquaFUELs-Taxonomy, Biology and Biotechnology, v. 6, p. 1-258, 2009.

KOMOLAFE, Oladapo et al. Biodiesel production from indigenous microalgae grown in wastewater. Bioresource technology, v. 154, p. 297-304, 2014.

MORAES, Iracema de Oliviera et al. Brazilian diversity in culture collection deveted to the identification and preservation of microorganisms useful in environmental, industrial and aplplied microbiology. In: ANTONIO, Mendez-vilas (Ed.). Microbes In Applied Research: Current Advances And Challenges. World Scientific, 2012.

MORAES, Iracema de Oliveira, et al. Spirulina platensis: process optimization to obtain biomass. Food Science and Technology, v. 33, p. 179-183, 2013.

NAUTIYAL, Piyushi; SUBRAMANIAN, K. A.; DASTIDAR, M. G. Kinetic and thermodynamic studies on biodiesel production from Spirulina platensis algae biomass using single stage extraction-transesterification process. Fuel, v. 135, p. 228-234, 2014.

NAUTIYAL, Piyushi; SUBRAMANIAN, K. A.; DASTIDAR, M. G. Production and characterization of biodiesel from algae. Fuel Processing Technology, v. 120, p. 79-88, 2014.
PELIZER, L. H.; MORAES, I. O. Development of solid state cultivation process for Spirulina platensis production. In: 14th European Congress on Biotechnology Barcelona, Spain 13-16 September 2009, Barcelona. Anais...14th European Congress on Biotechnology. London/England: Elsevier, 2009. v. 25. p. S222-S223.

PELIZER, Lúcia Helena; CARVALHO, João Carlos Monteiro de; MORAES, Iracema de Oliveira. Protein production by Arthrospira (Spirulina) platensis in solid state cultivation using sugarcane bagasse as support. Biotechnology Reports, v. 5, p. 70-76, 2015.

PELIZER, Lúcia Helena, MORAES, Iracema de Oliviera. A method to estimate the biomass of Spirulina platensis cultivated on a solid medium. Brazilian Journal of Microbiology, v. 45 n.3, p. 933-936, 2014.

SASSANO, Carlos Eduardo Nascimento; GIOIELLI, Luiz Antonio; CONVERTI, Attilio; MORAES, Iracema de Oliveira; SATO, Sunao; CARVALHO, João Carlos Monteiro de. Urea increases fed-batch growth and $\mathrm{y}$-linolenic acid production of nutritionally valuable cyanobacterium. Engineering in Life Sciences (Print), v. 14, p. 530-537, 2014.

TOKUŞOGLU, Ö. et al. Biomass nutrient profiles of three microalgae: Spirulina platensis, Chlorella vulgaris, and Isochrisis galbana. Journal of food science, v. 68, n. 4 , p. $1144-1148,2003$.

XU, Ruoyu; MI, Yongli. Simplifying the process of microalgal biodiesel production through in situ transesterification technology. Journal of the American Oil Chemists' Society, v. 88, n. 1, p. 91-99, 2011. 